\title{
AEROPLATES EXERCISE PROGRAM IN OBESITY TREATMENT ${ }^{1}$
}

\section{OBEZITE TEDAVISINDE AEROPLATES EGZERSIZ PROGRAMI}

\author{
Lütfi AKG ÜN $N^{1}$, Murat DEMIREZEN $N^{2}$, Sükran İpek YABUZ $Z^{3}$ \\ ${ }^{1-2-3}$ Afyonkarahisar Directorate of the Public Health, Afyon / Turkey
}

Öz: Günümüz sağlık anlayışı, bireyin sağlı̆̆ını koruyacak, sürdürecek ve geliştirecek davranışlar kazanması üzerine kurulmuştur. Egzersiz stres düzeyi ayarlanabilen en güçlü ilaçtır. Tanımlayıcı tipteki bu çalışmamız, 1 Ocak 2014 - 31 Aralık 2015 tarihleri arasında Afyonkarahisar Halk Sağlığı Müdürlüğü, Sağlıklı Yaşam Merkezi’ne başvuran 146 hasta üzerinde ve örneklem seçilmeden yapılmıştır. Hastaların sosyo-demografik özellikleri ve antropometrik ölçümleri anket formunda yer almıştır. Araştırmaya katılan bireyler her ay düzenli olarak telefonla kontrole çağrılmıştır. Hastaya verdiğimiz egzersiz reçetesi geri bildirim formları sayesinde hastaların düzenli egzersiz programını uyguladı̆̆ını bize göstermeleri istenmiştir. Hastaların verdiği kilo ortalaması $12.44 \pm 7.58$ olarak saptanmıştır. Kişinin fiziksel ve sosyal durumuna uygun, güvenli ve etkin bir egzersiz uygulandığında, multidisipliner yaklaşım kullanarak psikolojik destek sağlandığında hastanın uyumu ve egzersizin sürdürülebilirliği artar. Bu durum kilo kontrolü ve obeziteye bağlı hastalıkların tedavisini olumlu etkiler. Ayrıca, kişiselleştirilmiş, çok amaçlı, değiştirilmiş aero-pilates egzersiz programı, ağırlıklı olarak kilo kaybı, sağlıklı yaşam veya birçok hastalığın tedavisi için yapılan diğer egzersizler ve spor faaliyetlerine alternatif bir teknik olarak düşünülmüştür. Egzersiz bir ilaçtır. Bir egzersizin stres seviyesi düzenlenirse ve bir hastaya özgü reçete edilirse etkisi yüksek olur. Beklenmedik yaralanmalar ve hastalıklar önlenebilir. Bu kişiselleştirilmiş, çok amaçlı, değiştirilmiş aero-pilates egzersiz programı kolaydır, herhangi bir araç gereç gerektirmez, bireylerin sosyal statülerine uygundur, eğlencelidir, yaralanmalar açısından düşük risk taşır ve modifiye edilebilir. Her bireyde etkili ve verimli sonuçlar elde edilebilir. Bu nedenle, bu program diğerlerinden üstündür.

Anahtar Kelimeler: Egzersiz, Obezite, Önleme
Abstract: Today's concept of health is based on individual's attitudes to protect, maintain, and develop the well-being. Exercise is the most potent medication with an adjustable stress level. This descriptive study was conducted with 146 patients who visited the Wellness Center of Afyonkarahisar Directorate of the Public Health between January 2014 and December 2015. Socio-demographic characteristics and anthropometric measurements of patients were obtained. Participants were regularly recruited to the center for monthly checkups. It was asked from patients to show that they exactly applied the exercise plan by filling feedback forms. Patients were not obese in the end of the study. The average weight loss of participants was $12.44 \pm 7.58 \mathrm{~kg}$. When a safe and effective exercise appropriate to the physical and social condition of the person is applied, and when the psychological support is provided by using the multidisciplinary approach, participatory adaptation and sustainability increase and this positively affects the weight control and the treatment of obesity related diseases. Furthermore, personalized, multi-purpose, modified aero-pilates exercise program has been considered as an alternative technique to other exercises and sporting activities that are primarily performed for weight loss, healthy life, or treatment of many diseases. An exercise is a medication. When the stress level of an exercise is arranged and prescribed to an individual, it leads to high efficiency and unexpected injuries and diseases can be prevented. This personalized, multi-purpose, modified aero-pilates exercise program is easy, it does not require any tool, it is appropriate to the social status of individuals, it is enjoyable, there is a low risk for injuries, it can be modified according to each individual, and it is efficient. Therefore, this program is superior to others.

Key Words: Exercise, Obesity, Prevention

Doi: 10.17363/SSTB.2017.1.002

(1) Corresponding Author: Murat DEMIREZEN, Afyonkarahisar Directorate of the Public Health, Afyon / Turkey, drdemirezen1981@mynet.com, Received: 23/12/2016, Revision date: 02/02/2017, Accepted: 10/03/2017 Type of article (Research) Conflict of Interest: None / "None of Ethics Committee" 


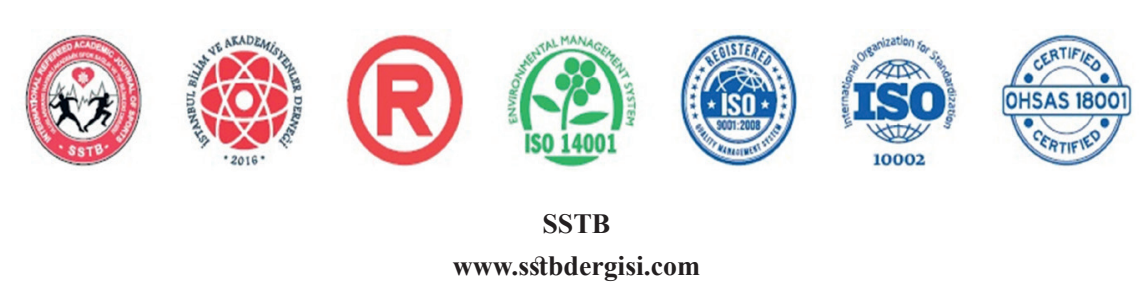

International Refereed Academic Journal of Sports, Health and Medical Sciences

January - February - March Issue 22 Winter Season Year: 2017

JEL CODE: I10-I11-I12-I18-I19 ID:320 K:419

ISSN Print: 2146-8508 Online 2147-1711

(ISO 18001-OH-0090-13001706 / ISO 14001-EM-0090-13001706 / ISO 9001-QM-0090-13001706 / ISO 10002-CM-0090-13001706)

(TRADEMARK)

(2015/04315- 2015-GE-18972)

\section{INTRODUCTION}

The aim of healthy lifestyle behaviors is not only preventing a disease but also improving individual's general health and well-being status (Edelman and Mandle, 1986; Arslan and Ceviz, 2007:213-217).

Various health problems are caused by immobile life-style and the lack of positive behaviors and attitudes towards the health concept (Arslan and Ceviz, 2007:213-217; Pender, 1987; Redland and Stuifbergen, 1993:427441). Furthermore, studies report that immobile life-style leads to various chronic diseases (Arslan and Ceviz, 2007:213-217; Costanzo, et, al., 2006:786-801; Lees and Booth, 2005:73-79).

Even though the most effective types of exercises are jogging, hiking, biking, boating, and swimming which can increase the aerobic capacity. These exercises may not be suitable for health, physical, social, economic statuses, and tastes of individuals. As it can be seen in Table 1, different types of exercises can lead to different contributions and nega- tive effects. Therefore, it is required to individualize these exercises in an effective and safe way and maximize their positive effects on individual's health status (Faulkner, et, al., 2014:46-54).

Exercise is the most potent medication with adjustable stress level. Exercise has important effects particularly on today's most important health problems such as obesity, cancer, cardiovascular diseases, and osteoclasis (Pedersen and Saltin, 2015:1-72). Even though the type of the exercise and the duration of sporting activities are not certain, there is a general consensus about the safety and efficiency of an exercise which should be suitable to an individual and lead to the regular exercise of large joints and muscles as well as the heart (Franklin, et, al., 2000:30-2457).

1. The short-term effect of this program is the disappearance of muscle aches on the 3rd day. Furthermore, the life quality is enhanced with its long term effects on the $20^{\text {th }}$ day and at the $6^{\text {th }}$ month and these effects are more persistent. 


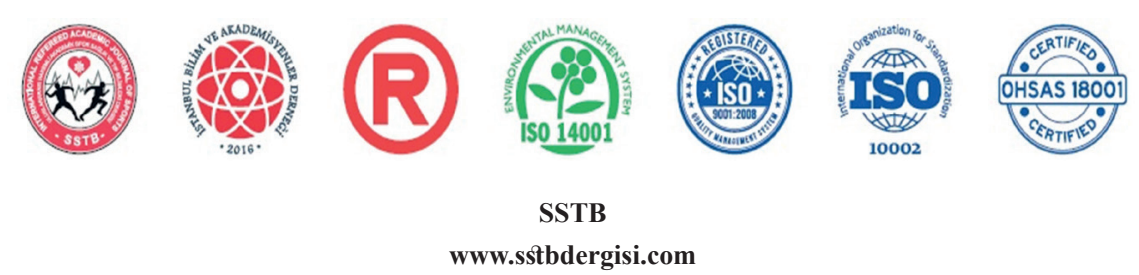

International Refereed Academic Journal of Sports, Health and Medical Sciences

January - February - March Issue 22 Winter Season Year: 2017

JEL CODE: I10-I11-I12-I18-I19 ID:320 K:419

ISSN Print: 2146-8508 Online 2147-1711

(ISO 18001-OH-0090-13001706 / ISO 14001-EM-0090-13001706 / ISO 9001-QM-0090-13001706 / ISO 10002-CM-0090-13001706) (TRADEMARK)

(2015/04315- 2015-GE-18972)

Table 1. The Most Frequently Used Exercises, Their Contribution to the Person, and Their Negative Effects (Franklin et al, 2000:30-2457)

\begin{tabular}{llll}
\hline & EXERCISE & CONTRIBUTION & NEGATIVE EFFECT \\
\hline 1 & Walking Exercise & Losing weight & Weak Exercise, Risky for Knee and Waist \\
\hline 2 & Jogging & Losing weight and strength & Risky for Knee and Waist \\
\hline 3 & Cycling & Losing weight & Weak Exercise \\
\hline 4 & Weight Work & Strength & High risk for injury \\
\hline 5 & Swimming & Losing weight & Risky in Diabetes patients \\
\hline 6 & Water walking & Losing weight & Risky in Diabetes patients \\
\hline 7 & Pilates & Stretching Exercise Provides & Injury risk \\
\hline 8 & Aero-Pilates Exercise & Losing weight & Safe and Effective \\
\hline
\end{tabular}

The aim of this study is to evaluate the health status of participants who regularly visit wellness centers with the help of nutritionist, exercise specialist, psychologist, and child development specialist. Furthermore, it is also aimed to show the effectiveness of the multipurpose, personalized, modified, and aeroplates exercise program.

This descriptive study was conducted with 146 patients who visited the Wellness Center of Afyonkarahisar Directorate of the Public Health between 1 January 2014 and 31 December 2015. No sampling method was used. Socio-demographic characteristics and anthropometric measurements of the patients were included in the survey. Multidisciplinary approach treatment was applied to obese individuals who were admitted to the wellness center.

\section{METHODS}

\section{Multidisciplinary approach treatment}

Determination of the general health status (check-up)

Identification of the person's obesity

$>$ Determining the individual's obesity profile (weight, height, waist circumference, hip circumference, waist/hip circumference, body mass index (BMI))

$>$ Determination of the exercise type to be recommended according to the target

$>$ Determination of the purpose of the program to be implemented (losing weight, weight protection, flexibility vs.) 


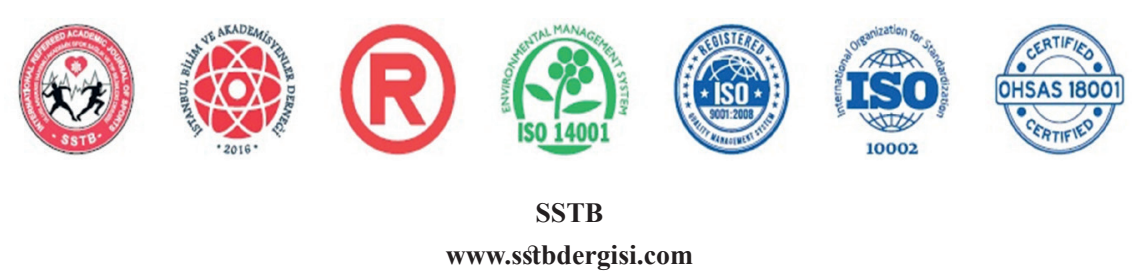

International Refereed Academic Journal of Sports, Health and Medical Sciences

January - February - March Issue 22 Winter Season Year: 2017

JEL CODE: I10-I11-I12-I18-I19 ID:320 K:419

ISSN Print: 2146-8508 Online 2147-1711

(ISO 18001-OH-0090-13001706 / ISO 14001-EM-0090-13001706 / ISO 9001-QM-0090-13001706 / ISO 10002-CM-0090-13001706) (TRADEMARK)

(2015/04315- 2015-GE-18972)

$>$ Implementation of multi-purpose, personalized, modified, aeroplates exercise program recommended to the individual

$>$ Evaluation of the compliance of an individual to the multi-purpose, personalized, modified, aeroplates exercise program

$>$ Prescribing the multi-purpose, personalized, modified, aeroplates exercise program (Type of exercise, number of sessions, severity and duration of exercise are adjusted according to an individual)

Multi-purpose, personalized, modified, aeroplates exercise program (Figure 1): This program is composed of 15 movements which are performed on both horizontal and vertical axes. It takes 10 to 12 minutes and movements do not lead to increase in blood cortisol levels. This exercise program is performed by adjusting the stress level. This program is composed of horizontal and vertical movements in order to protect the joints from the negative effects of the gravity. For this reason, risky movements are excluded. There are 15 safe movements in the exercise program that allows the exercise of large joints and muscles. These movements are sequentially listed starting from easy to hard and re- peated movements are numbered. Movement repeat number was recommended as 10 as it is in case of body building exercises.

It is possible to exclude some movements, decrease the number of movement repeats, and modify the movements according to the physical, social, and health conditions of individuals. Modifications improve the compliance and sustainability and thus it is possible to remove the risk of injury.

A feedback form was prepared and it was asked from patients to show us that they exactly applied the exercise plan by filling feedback forms and bringing them to us each month (Figure 2). The exercise program movements can be seen in Figure 3. The directions of each step in the exercise program can be seen below;

1. Move your legs as cycling while lying down on the ground. Please perform it primarily with right and then with the left leg.

2. While lying down on the ground, bend your leg and pull your knee onto your chest in 1 second and leave it back in 2 seconds. Please perform it primarily with right and then with the left leg. 


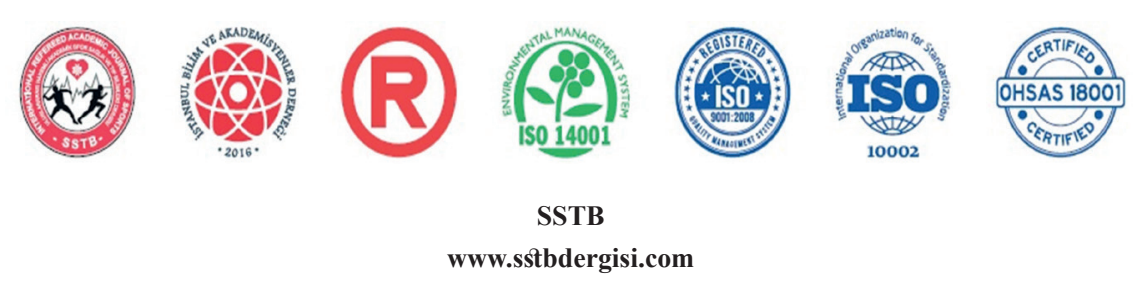

International Refereed Academic Journal of Sports, Health and Medical Sciences

January - February - March Issue 22 Winter Season Year: 2017

JEL CODE: I10-I11-I12-I18-I19 ID:320 K:419

ISSN Print: 2146-8508 Online 2147-1711

(ISO 18001-OH-0090-13001706 / ISO 14001-EM-0090-13001706 / ISO 9001-QM-0090-13001706 / ISO 10002-CM-0090-13001706) (TRADEMARK)

(2015/04315- 2015-GE-18972)

Figure 1. In the Multipurpose, Personalized, Modified, Aaeroplates Exercise Program, the Movements in the Horizontal Plane were Prioritized in order to Reduce the Adverse Effects of Gravity on the Joints.

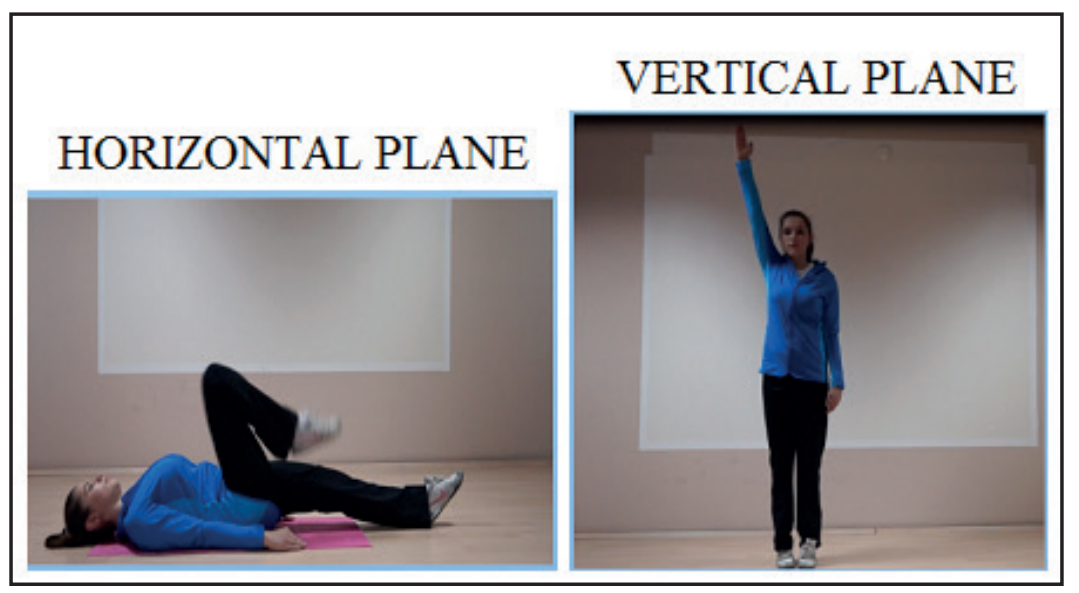

3. While lying down on the ground, rapidly lift your leg up (1 second) and then slowly lower your leg down to the ground (2 seconds). Please perform it primarily with right and then with the left leg.

4-5. While lying down on the ground, circle your straight leg clockwise and then repeat the movement counterclockwise. Please perform it primarily with right and then with the left leg.

6. Lie on your side on the ground and raise your straight leg quickly towards your head (1 second) and lower your leg down on the ground ( 2 seconds). Please perform it primarily with right and then with the left leg.
7. Lie on your side on the ground and pull your leg to your stomach (1 second) and let it go back straightly (2 seconds). Please perform it primarily with right and then with the left leg.

8-9. Lie on your side on the ground and circle your straight leg clockwise and then repeat the movement counterclockwise. Please perform it primarily with right and then with the left leg.

10. Lie on your side on the ground and perform the cross walk movement. Please perform it primarily with right and then with the left leg.

11. Stand up, rise on your feet, and raise primarily your right arm up. Turn your arms forward. Afterwards, lower your arm and 


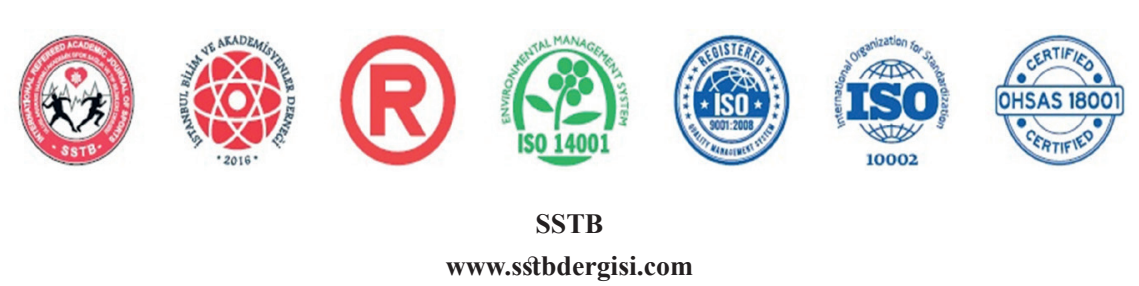

International Refereed Academic Journal of Sports, Health and Medical Sciences

January - February - March Issue 22 Winter Season Year: 2017

JEL CODE: I10-I11-I12-I18-I19 ID:320 K:419

ISSN Print: 2146-8508 Online 2147-1711

(ISO 18001-OH-0090-13001706 / ISO 14001-EM-0090-13001706 / ISO 9001-QM-0090-13001706 / ISO 10002-CM-0090-13001706)

(TRADEMARK)

(2015/04315- 2015-GE-18972)

stand up again on your feet. (1 second up and 2 seconds down) Repeat the movement with the left arm.

12. Stand up, rise on your feet, and raise primarily your right arm up. Turn your arms backward. Afterwards, lower your arm and stand up again on your feet. (1 second up and 2 seconds down) Repeat the movement with the left arm.

13. Stand up, rise on your feet, and make circles with your shoulders by turning them from front to back. (1 second up and 2 seconds down)

14. Stand up, straighten your arms out sideways at shoulder height with your palms facing up and stretch backward. (1 second backward and 2 seconds turn to the straight standing up position)
15. Stand up, rise on your feet, lift your arms up, and turn back to standing position. (1 second lifting arms up and 2 seconds turn to the straight standing up position)

\section{FINDINGS}

There were 131 female and 15 male patients in the study $\left(\mathrm{N}_{\text {total }}=146\right)$. The mean age of patients was $40.00 \pm 11.0$, the mean height of patients was $160.31 \pm 7.12$, and the mean weight of patients was $83.65 \pm 17.03$. Furthermore, their first BMI was $32.53 \pm 6.25$ and the final BMI was 27.68 \pm 4.54 . BMI values of 146 patients reduced below 30 with the help of the exercise program and there was an improvement in their obesity level. The mean weight loss was detected as $12.44 \pm 7.58$. 


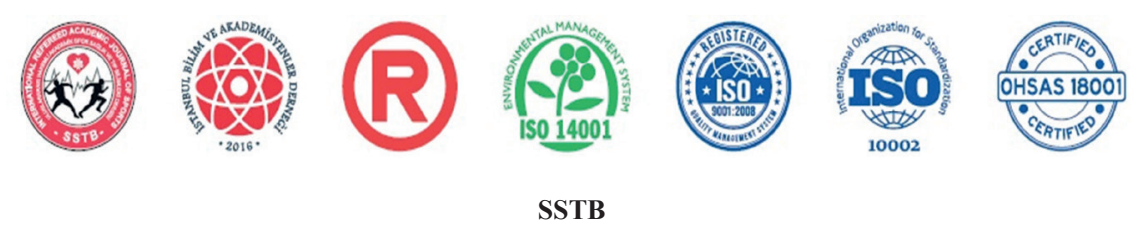

www.sstbdergisi.com

International Refereed Academic Journal of Sports, Health and Medical Sciences

January - February - March Issue 22 Winter Season Year: 2017

JEL CODE: I10-I11-I12-I18-I19 ID:320 K:419

ISSN Print: 2146-8508 Online 2147-1711

(ISO 18001-OH-0090-13001706 / ISO 14001-EM-0090-13001706 / ISO 9001-QM-0090-13001706 / ISO 10002-CM-0090-13001706) (TRADEMARK)

(2015/04315- 2015-GE-18972)

Figure 2. The Feedback Form of the Multi-purpose, Personalized, Modified, Aeroplates Exercise Program Prepared for the Obesity Treatment

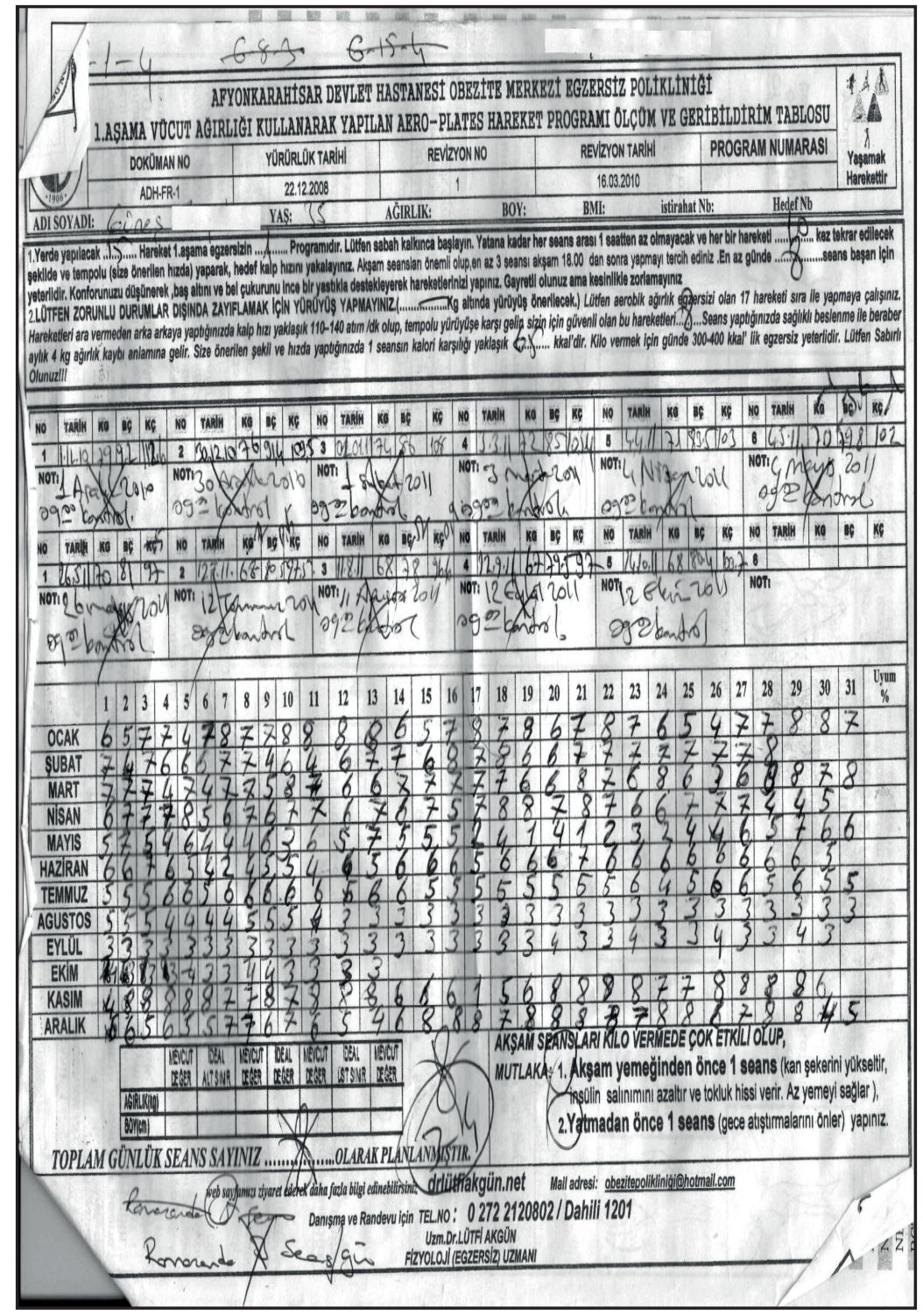




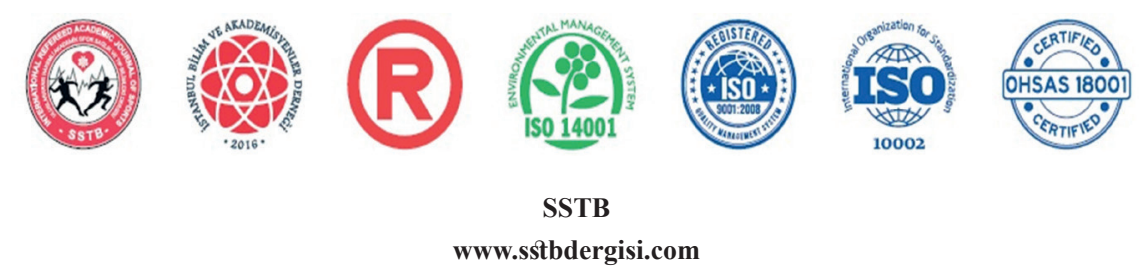

International Refereed Academic Journal of Sports, Health and Medical Sciences

January - February - March Issue 22 Winter Season Year: 2017

JEL CODE: I10-I11-I12-I18-I19 ID:320 K:419

ISSN Print: 2146-8508 Online 2147-1711

(ISO 18001-OH-0090-13001706 / ISO 14001-EM-0090-13001706 / ISO 9001-QM-0090-13001706 / ISO 10002-CM-0090-13001706) (TRADEMARK)

(2015/04315- 2015-GE-18972)

Figure 3. The Multi-purpose, Personalized, Modified, Aeroplates Exercise Program (Franklin, et, al, 2000)

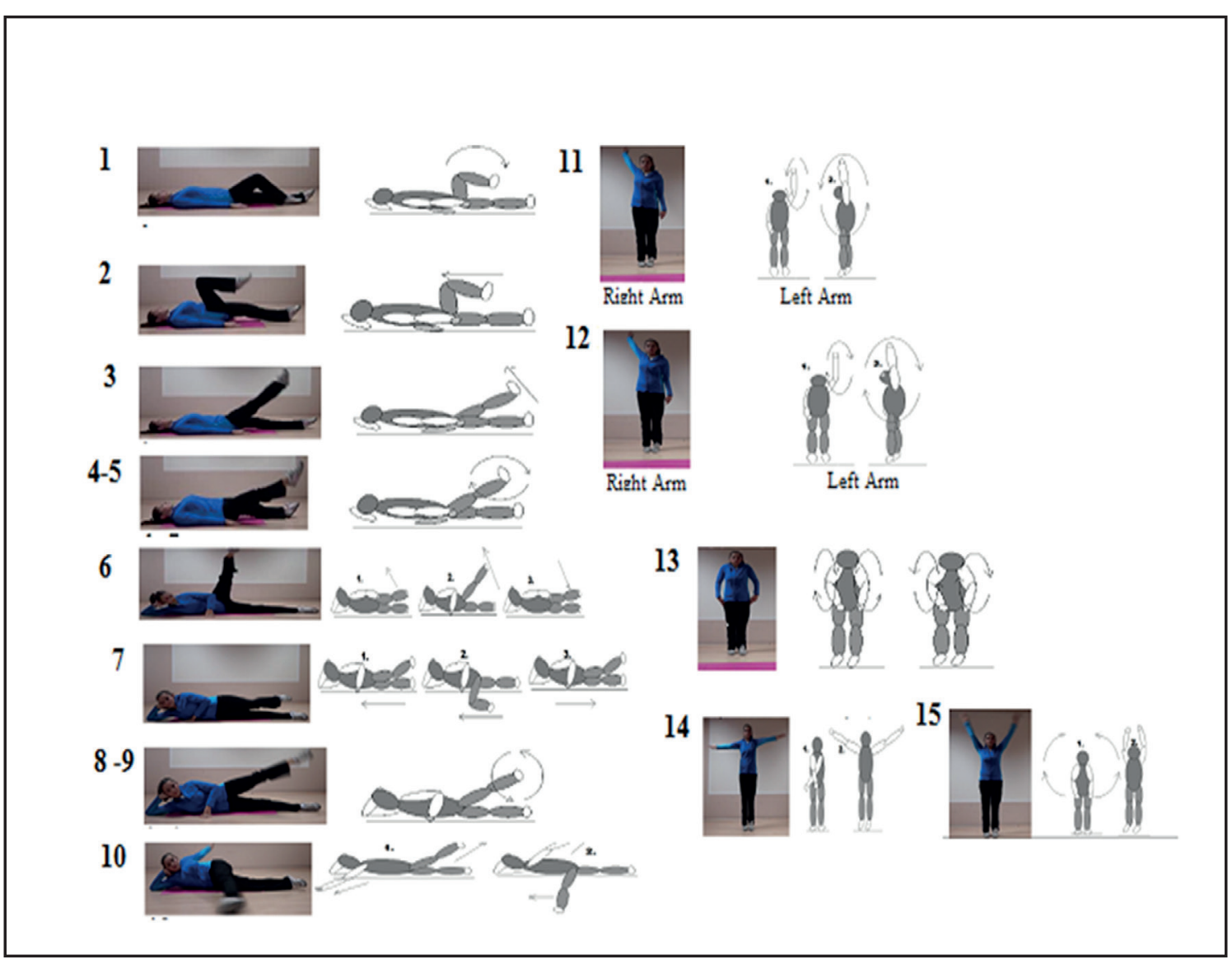

\section{DISCUSSION}

In this study, it was shown that when the multipurpose, personalized, modified, aeroplates exercise program is performed as it is prescribed, it leads to positive health outcomes with a high efficiency. This exercise program was applied to more than two hundred thousand patients in 8 years and there was no negative feedback. In order to consider an ex- ercise program as efficient, it should lead to successful weight loss and weight protection, it should facilitate the treatment of diseases (such as diabetes and hypertension) related to muscle mass loss, and it should prevent the knee and back issues due to weight loss.

Similar to studies of Montesi et al., De Miguel-Etayo et al., and Bocca et al., it has been shown that multidisciplinary approach 


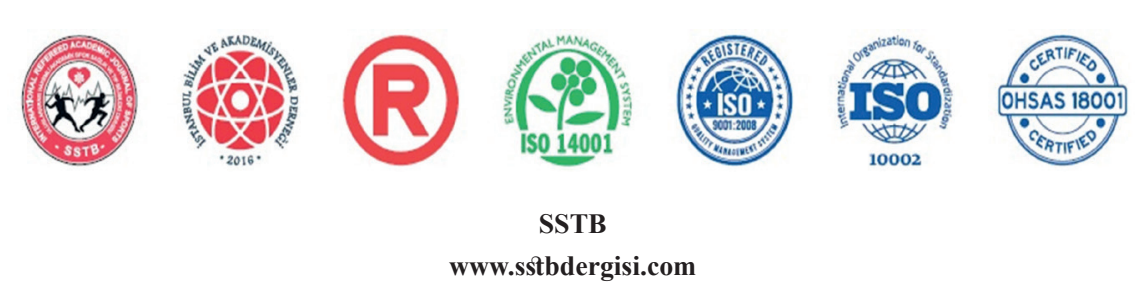

International Refereed Academic Journal of Sports, Health and Medical Sciences

January - February - March Issue 22 Winter Season Year: 2017

JEL CODE: I10-I11-I12-I18-I19 ID:320 K:419

ISSN Print: 2146-8508 Online 2147-1711

(ISO 18001-OH-0090-13001706 / ISO 14001-EM-0090-13001706 / ISO 9001-QM-0090-13001706 / ISO 10002-CM-0090-13001706) (TRADEMARK)

(2015/04315- 2015-GE-18972)

and regular exercises in the treatment of obesity are successfully applied (Montesi, et, al., 2016:37-46; De Miguel-Etayo et, al., 2016:84-87; Sumithran, et, al., 2016:101107). Furthermore, it has recently been shown in meta-analysis of randomized controlled trials that obesity and related diseases can be treated and life quality can be improved by performing a regular and appropriate exercise in almost every period of life such as childhood, adolescence, and pregnancy (Freitas et al., 2016; Magro-Malosso, et, al., 2016; García-Hermoso, et, al., 2017). As it has been indicated in a study of Holzapfel et al., follow up of patients with phone calls is also very important in the obesity treatment (Holzapfel, et, al., 2016:230-240).

Following the patient by phone calls increases the motivation of the patient. This is very important in the success of the exercise program. Therefore, regular follow ups in wellness centers with the help of phone calls or face-to-face interviews are very important in obtaining successful health outcomes in terms of obesity treatment (Holzapfel, et, al., 2016:230-240). A recent clinical trial has been completed and it has been claimed that inpatient obesity can be prevented with the phone follow-up (Inpatient Obesity Intervention with Phone Follow-up).

Our study shows that when the obesity is regularly followed up with the multidisciplinary approach, it can be successfully treated. When a safe and effective exercise appropriate to the physical and social condition of the person is applied, and when psychological support is provided by using the multidisciplinary approach, participatory adaptation and sustainability increase and this positively affects the weight control and the treatment of obesity related diseases.

Furthermore, personalized, multi-purpose, modified aero-pilates exercise program has been considered as an alternative technique to other exercises and sporting activities that are primarily for weight loss, healthy life, or treatment of many diseases. An exercise is a medication. When the stress level of an exercise is arranged and prescribed to an individual, it leads to high efficiency and unexpected injuries and diseases can be prevented.

This personalized, multi-purpose, modified aero-pilates exercise program is easy, it does not require any tool, it is appropriate to the social status of individuals, it is enjoyable, there is a low risk for injuries, it can be modified according to each individual and it is efficient. Therefore, this program is superior to others.

\section{REFERENCES}

ARSLAN, C., CEVIZ, D., (2007). Ev Hanım1 ve Çalışan Kadınların Obezite Prevalansı ve Sağlıklı Yaşam Biçimi Davranışları- 


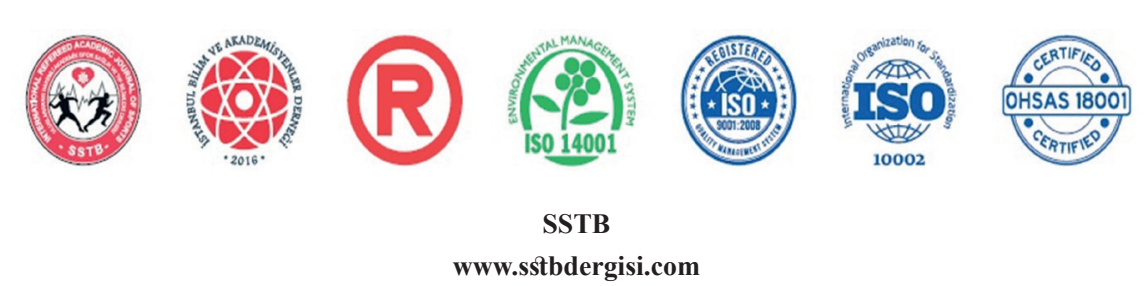

International Refereed Academic Journal of Sports, Health and Medical Sciences

January - February - March Issue 22 Winter Season Year: 2017

JEL CODE: I10-I11-I12-I18-I19 ID:320 K:419

ISSN Print: 2146-8508 Online 2147-1711

(ISO 18001-OH-0090-13001706 / ISO 14001-EM-0090-13001706 / ISO 9001-QM-0090-13001706 / ISO 10002-CM-0090-13001706) (TRADEMARK)

(2015/04315- 2015-GE-18972)

nın Değerlendirilmesi. F.Ü.Sağ.Bil.Tıp Derg., 21 (5): 211 - 220

COSTANZO, C., WALKER, S.N., YATES, B.C., MCCABE, B., BERG, K., (2006). Physical activity counselling for older women. West J Nurs Res Suppl, 28(7): 786-801

DE MIGUEL-ETAYO, P., MURO, C., SANTABÁRBARA, J., LÓPEZ-ANTÓN, R., MORANDÉ, G., MARTÍNMATILLAS, M., AZCONA-SAN JULIÁN, M.C., MARTI, A., CAMPOY, C., MARCOS, A., MORENO, L.A., GARAGORRI, J.M., (2016). Behavioral predictors of attrition in adolescents participating in a multidisciplinary obesity treatment program: EVASYON study. Int J Obes (Lond), 40(1):84-7. DOI: 10.1038/ijo.2015.183

EDELMAN, C., MANDLE, C.L., (1986). Health Promotion throughout the Lifespan, $6^{\text {th }}$ ed. The C.V.Mosby Company, St Luis, Toronto, Princeton

\section{FAULKNER, M.S., MICHALISZYN,} S.F., HEPWORTH, J.T., WHEELER, M.D., (2014). Personalized Exercise for adolescents With Diabetes or Obesity Biol Res Nurs., 16(1): 46-54. DOI: $10.1177 / 1099800413500064$
FRANKLIN, B.A., WHALEY, M.H. , HOWLEY, E.T. ,BALADY, G.J., (2000). ACSM's guidelines for exercise testing and prescription, $6^{\text {th }}$ ed. Lippincott Williams \& Wilkins

2. FREITAS, C.R., GUNNARSDOTTIR, T., FIDELIX, Y.L., TENÓRIO, T.R., LOFRANO-PRADO, M.C., HILL, J.O., PRADO, W.L., (2016). Effects of a psychological intervention on the quality of life of obese adolescents under a multidisciplinary treatment. J Pediatr (Rio J). PII: S0021-7557(16)30236-4. DOI: 10.1016/j.jped.2016.05.009. [Epub ahead of print]

3. GAR CIA - HER MOSO, A., GONZÁLEZ-RUIZ, K., TRIANA-REINA, H.R., OLLOQUEQUI, J., RAMIREZ-VÉLEZ, R., (2017). Effects of Exercise on Carotid Arterial Wall Thickness in Obese Pediatric Populations: A Meta-Analysis of Randomized Controlled Trials. Child Obes. DOI: 10.1089/chi.2016.0265. [Epub ahead of print]

HOLZAPFEL, C., MERL, M., STECHER, L., HAUNER, H., (2016). One-Year Weight Loss with a Telephone-Based Lifestyle Program. Obes Facts, 26;9(4):230240. DOI:10.1159/000445381 


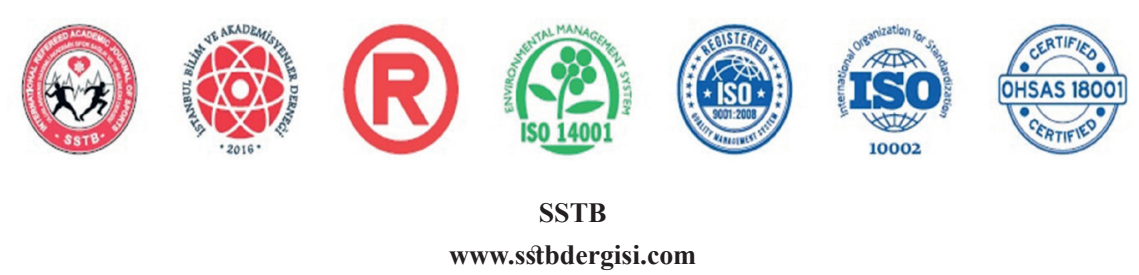

International Refereed Academic Journal of Sports, Health and Medical Sciences

January - February - March Issue 22 Winter Season Year: 2017

JEL CODE: I10-I11-I12-I18-I19 ID:320 K:419

ISSN Print: 2146-8508 Online 2147-1711

(ISO 18001-OH-0090-13001706 / ISO 14001-EM-0090-13001706 / ISO 9001-QM-0090-13001706 / ISO 10002-CM-0090-13001706) (TRADEMARK)

(2015/04315- 2015-GE-18972)

LEES, S.J., BOOTH, F.W., (2005). Physical inactivity is a disease. World Rev Nutr Diet, 95: 73-79

MAGRO-MALOSSO, E.R., SACCONE, G., DI MASCIO, D., DI TOMMASO, M., BERGHELLA, V., (2016). Exercise during pregnancy and risk of preterm birth in overweight and obese women: a systematic review and meta-analysis of randomized controlled trials. Acta Obstet Gynecol Scand., DOI: 10.1111/ aogs.13087. [Epub ahead of print]

MONTESI, L., EL GHOCH, M., BRODOSI, L., CALUGI, S., MARCHESINI, G., DALLE GRAVE, R., (2016). Long-term weight loss maintenance for obesity: a multidisciplinary approach. Diabetes Metab Syndr Obes, 26;9:37-46

PEDERSEN, B.K., SALTIN, B., (2015). Exercise as medicine - evidence for prescribing exercise as therapy in 26 different chronic diseases Scand J Med Sci Sports, 25(S3): 1-72. DOI: 10.1111/ sms. 12581
PENDER, N.J., (1987). Health promotion in nursing practice, $2^{\text {nd }}$ ed. Norwalk CT, California

REDLAND, A.R., STUIFBERGEN, A.K., (1993). Stategies for maintenance of health-promoting behaviour. Nurs Clin North Am Suppl, 28(2); 427-441

SUMITHRAN P., PRENDERGAST L.A., HAYWOOD C.J., HOULIHAN C.A., PROIETTO J., (2016). Review of 3-year outcomes of a very-low-energy diet-based outpatient obesity treatment programme. Clin Obes. 2016 Apr;6(2):1017. DOI: 10.1111/cob.12135. PubMed PMID: 26841953

\section{INTERNET SOURCES}

Effects of Nutrition Meal Replacement and Individualized Exercise Prescription on Type 2 Diabetes Available at: https://clinicaltrials.gov/ct2/show/ NCT02984605 [accessed 12.01.2017]

\section{Inpatient Obesity Intervention With Phone} Follow-up. Available at: https://clinicaltrials.gov/ct2/show/NCT01920620 [accessed 12.01.2017] 